\title{
Loch Ágnes
}

\author{
Budapesti Gazdasági Egyetem \\ Kereskedelmi, Vendéglátóipari és Idegenforgalmi Kar \\ Idegen Nyelvi és Kommunikációs Intézet \\ Gazdasági Szaknyelvek Tanszék
}

\section{Szaknyelvi projektfeladatok: kooperáció és (ön)értékelés a szaknyelvi órán}

\author{
https://doi.org/10.48040/PL.2020.29
}

\begin{abstract}
Az elmúlt időszakban nagyszabású tantervi reformra került sor a Budapesti Gazdasági Egyetem alapképzési szakjain. A tanterv átalakitását oktatásmódszertani fejlesztések egészitették ki, melyek célja az oktatás hatékonyságának növelése a hallgatói motiváció erösitésén keresztül. Az új generációk tanulási stílusára, a tanulással kapcsolatos motivációira és elvárásaira vonatkozó vizsgálatok azt mutatják, hogy a korábbi tudásközpontú oktatás helyett érdemes a tevékenységés tapasztalatalapú, tudásmegosztást is lehetôvé tevő módszerek felé fordulni. Ez a felismerés tükrözödik az egyetem stratégiai célkitüzéseiben, amelyek között szerepel az élményalapú tanulási környezet megteremtése. Ennek megvalósitását az intézmény olyannyira fontosnak tartja, hogy pályázati rendszerrel segíti az új innovatív tananyagok és tantárgyi módszertanok fejlesztését. Ennek keretében az egyetem Kereskedelmi, Vendéglátóipari és Idegenforgalmi Karának szaknyelvi tanszékén angol és spanyol nyelven összesen 20 szaknyelvi projektfeladat kidolgozására került sor. A dolgozatban bemutatásra kerülnek a projektek kidolgozásának fö szempontjai, a projektek felépitése, továbbá a projektek elsö bevezetésének tapasztalatai. A projekt, mint oktatási módszer kihívások elé állitja a tanárt és a tanulót. A legnagyobb nehézséget talán az elvégzett munka értékelése okozza, hiszen a csoportos munka eredményeképpen létrejött produktum alapján gyakran lehetetlen az egyéni kontribúció értékelése. Az alábbiakban bemutatásra kerülnek a tanulási folyamatot támogató alternativ értékelési lehetöségek is.
\end{abstract}

Kulcsszavak: élményalapú oktatás, kooperáció, (ön)értékelés, projektfeladat, projekt-fejlesztés

Az elmúlt időszakban a Budapesti Gazdasági Egyetemen (BGE) nagyszabású tantervi reformra ${ }^{1}$ került sor, amelynek során áttekintésre és szükség esetén módosításra került az egyes képzések tantárgyi struktúrája (tantárgyak, óraszámok, kreditszámok), valamint megújultak a tantárgyi tartalmak. A tantervreformhoz kapcsolódóan módszertani fejlesztésekre is sor került az oktatás hatékonyságának növelése céljából. A fejlesztéseket az intézmény belső pályázati lehetöséggel is megtámogatta, amelynek keretében több tantárgyból is projektfeladat-fejlesztésre került sor.

Napjainkban a tudásátadás-központú oktatást egyre jobban felváltja a tevékenység és tapasztalat alapú oktatás (Andresen et al., 2001; Bakti et al., 2018;

Forrás: https://uni-bge.hu/documents/SZABALYOZO_DOKUMENTUMOK/Rektorikancellari-kozos-utasitas/DocumentFolder 
Kolb - Kolb, 2013), valamint a tudásmegosztásra épülő tanulás (Bodnár, 2014; Gönczöl, 2009; Koltói, 2009). Ezen oktatási és tanulási formák egyben lefedik az élményalapú oktatás fogalmát. Élményalapú oktatás alatt nem a szórakozva/szórakoztatva tanulást értjük, hanem a valós, megélt tapasztalat alapján történő tanulást. Az oktatási módszertannak ilyen irányú változtatása megfelel a BGE élményalapú oktatási környezet létrehozására vonatkozó stratégiai célkitüzésének ${ }^{2}$.

A projektmódszer alkalmas lehet az élményalapú tanulás megtapasztalásra. Ez a munkaforma nem ismeretlen az oktatásban, az utóbbi években azonban egyre nagyobb hangsúlyt kap, mert úgy tünik, a tanulásnak ez a formája jól tud alkalmazkodni a megváltozott tanulási gyakorlatokhoz és lehetőségekhez, továbbá alkalmas lehet a hallgatói motiváció növelésére is (Gibbes - Carson, 2013; Török - Kétyi, 2018).

A módszernek komoly szakirodalma van (Henry, 2005; Johnson, et al., 2014; Kauchak - Eggen, 2012; Lee et al., 2014). Elméleti hátterét a kooperatív tanulás adja (Johnson et al., 2014), amely túlmutat az egyszerü csoportmunkán. Míg az egyszerü tanórai csoportmunka esetében az elsődleges cél a tananyag elsajátítása, addig a kooperatív módszerek esetében a tananyag elsajátítása és a társas készségek fejlesztése egyformán fontos cél. Bármely kooperatív módszer sikerének feltétele, hogy mind a tananyagelsajátításban, mind pedig a társas készségek fejlesztésében az egyéni tanulás/fejlődés a csoporttagok természetszerüen bekövetkező támogatása mellett történjen (Sándor - Szirtesné, 2016).

A kooperatív módszereken belül a projektmunka olyan, nagyfokú önállóságot és egyben a csoporttagok egymásrautaltságát feltételező kooperatív tanulási forma, amelynek középpontjában több, egymást kiegészítő vagy egymásra épülő tevékenységből álló komplex feladat áll. Thomas (2000) a projektalapú tanításnak/tanulásnak öt fontos feltételét definiálja, melyek a következők: (1) a projekt a tanterv fontos alkotóeleme, szerepe nem periférikus; (2) a projekt olyan kérdésre/problémára fókuszál, amely az adott szakma vagy tudományterület fogalmainak, elveinek és gyakorlatának mélyebb megértését szolgálja; (3) a projekt konstruktív, felfedező jellegü tevékenységet generál; (4) a projekt tanulóközpontú, a hagyományos tanári szerep megszünik, végül (5) a projekt valós feladat, nem iskolaízü, autentikus tevékenységekbe vonja be a tanulót.

Összefoglalóan a módszer a tanulási folyamatnak olyan alakítása vagy másképp fogalmazva olyan oktatási stratégia, amelyben a tanulók önálló tevékenységeken keresztül egy komplex témát dolgoznak fel. A pedagógus a kereteket teremti meg ehhez, és facilitátorként, tanácsadóként a háttérből segít és támogat. A projektoktatás során a tanulók maguk határozzák meg a témát, tervezik és szervezik meg a tanulás, a munka folyamatát, a témával való

\footnotetext{
${ }^{2}$ Budapesti Gazdasági Egyetem Intézményfejlesztési Terve, 2016-2020
} 
foglalkozás módját és a munka eredményeinek a bemutatását. A szaknyelvoktatásban a projektmunka célja egy nyelvi produktum létrehozása, amely egyben a sikeres együttmüködést is bizonyítja.

A projektmunka a tantárgyi tematikára épül, de az ismeretanyag elsajátításán túl sokoldalúan szolgálja a kompetenciafejlesztést is. Az oktatásban jelenleg legelfogadottabb kompetenciamodellt az Európa Tanács dolgozta ki (Council of Europe, 2016), amely a 21. század igényei alapján határozza meg a kompetencia fogalmát és tartalmát a tudás, a készségek, az attitüd és az autonómia/tanulói felelősség területén (1. ábra). Egy-egy projektfeladat éppen komplexitása okán alkalmas lehet számos kompetencia-terület egyidejü fejlesztésére.

1. ábra. Kompetenciamodell (Council of Europe, 2016)

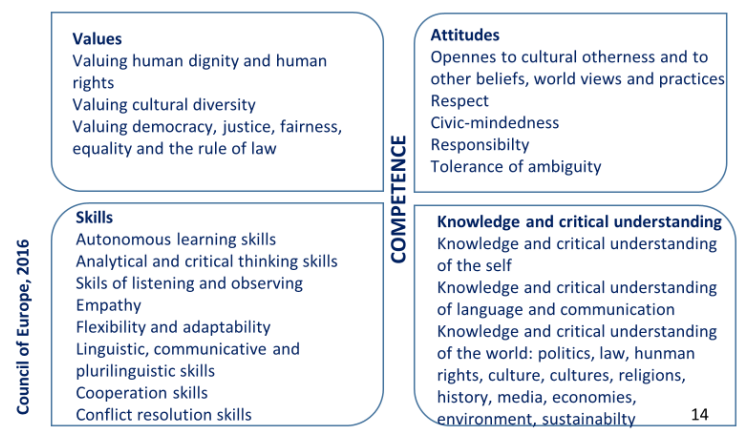

A projektmódszer kihívások elé állítja a tanárt és a tanulót is, hiszen a szerepek megváltoznak és a tanulási/tanítási szituáció észrevehetően eltér a hagyományostól (Condliffe et al., 2017): megváltozik az órai és órán kívüli tevékenységek jellege és aránya, az egyéni és csoportos munka aránya, továbbá jelentősen megnő a tanulói autonómia és felelősség szerepe. Éppen ezek a változások ugyanakkor azok, amelyek a munkahelyi környezetre, ill. az élethosszig tartó tanulás helyzeteire felkészíthetik a hallgatókat. Egyrészt a kollaborációra és tudásmegosztásra épülő tevékenységek fejlesztik a hallgatók együttmüködési készségeit és jártasságot nyújtanak a team-munkában, ami hozzájárul a versenyképességükhöz a munkaeröpiacon. Másrészt az ismeretanyag bővülése és a munkaerőpiaci elvárások várható gyors változásai miatt szükség van arra, hogy a hallgatók képessé váljanak a motivációik és a céljaik azonosítására és a saját tanulási tevékenységük autonóm megszervezésére akár egyénileg, akár csoportban (Jakabné Baján - Balla, 2012; Edwards, 1997; London, 2011).

A projektalapú oktatás legnagyobb kihívása valószínüleg az értékelés, hiszen mind a tanulási folyamat és annak hatékonysága, mind az eredmény, a végső teljesítmény egyéni értékelése komoly nehézségekbe ütközik (Gibbes Carson, 2013; Thomas, 2000). A projektfeladatok értékelése általában az output 
alapján történik és a csoport közös értékelést kap. Amennyiben az értékelés érdemjegyet is jelent, a csoport tagjai általában ugyanazt az osztályzatot kapják, amit az egyes csoporttagok igazságtalannak tarthatnak. Mindez frusztrációhoz és motivációvesztéshez vezethet ${ }^{3}$. Az is előfordulhat, hogy a tanár - mivel maga is tudja, hogy az egyéni fejlődést, az egyéni teljesítményt nem feltétlenül lehet megragadni - eltekint az érdemi értékeléstől és az osztályzattól és csupán általános visszajelzést ad a munkáról. Mivel a projektfeladatok általában komplex feladatok és nem kevés munkabefektetést igényelnek a résztvevőktől, ez a megoldás éppoly frusztráló a többség számára, mint az esetleg igazságtalannak tartott egyenlősdi az értékelésnél.

\section{Szaknyelvi projektfeladatok a Turizmus-Vendéglátás szakon}

Az intézmény által kínált lehetőséggel élve a Gazdasági Szaknyelvek Tanszékén angol és spanyol nyelvü projektfeladatok készültek a Turizmus-Vendéglátás Szaknyelv címü tantárgy oktatásának kiegészítésére. Mindkét nyelvből 10-10 projektfeladat készült el részletes feladatleírással, feladatlapokkal, tanári instrukciókkal és értékelési javaslattal. A projektfeladatok részben strukturált projektnek minősülnek, mivel a témát és az előkészítő anyagokat a tanár biztosítja, a feldolgozandó anyagot azonban a hallgatók önállóan gyűjtik össze.

A projektfeladatok elkészítésének számos pedagógia célja volt, melyek az alábbi, esetenként átfedő kategóriákba rendezhetők.

Szakspecifikus szakmai ismeretek és készségek bővítése:

- a meglévő szakmai ismeretek aktivizálása,

- szakmai jártasság szerzése valós feladatok elvégzésében (pl. adatgyüjtés, adatfeldolgozás, eredmények prezentálása).

Idegennyelv-tanulási és kommunikációs célok:

- nyelvi és kommunikációs ismeretek és készségek integrálása,

- idegen nyelvi és kommunikációs készségek fejlesztése,

- szóbeli és írásbeli kommunikációs müfajokban jártasság szerzése,

- nyelvvizsga-felkészülés.

Társas készségek fejlesztése:

- együttműködési készségek fejlesztése

\footnotetext{
${ }^{3}$ A BGE Pedagógia Tanszékének 2014-es felmérése szerint a hallgatók többsége elutasítja a csoportos projektmunkát, mint a teljesítményértékelés alapját. A leginkább elkötelezett diákok kihasználhatónak és vesztesnek érzik magukat társaik helyett végzett többletmunkájuk miatt.
} 
Módszertani célok a hatékonyság növelésére:

- élményalapú tanulás (learning by doing)

Nyelvtanuláson túlmutató tanulási célok:

- önállóság és felelősségvállalás fejlesztése.

Az angol nyelvü Turizmus-Vendéglátás Szaknyelv tantárgy tematikája 14 témát tartalmaz, amelyek közül kilenc témához készült összesen tíz projektfeladat (1. táblázat).

1. táblázat. A Turizmus-Vendéglátás Szaknyelv témái

\begin{tabular}{|c|l|c|}
\hline $\begin{array}{c}\text { Oktatási } \\
\text { hét }\end{array}$ & \multicolumn{1}{|c|}{ Téma } & $\begin{array}{c}\text { Projektek } \\
\text { száma }\end{array}$ \\
\hline 1. & A turizmus szerepe a gazdaságban & 1 \\
\hline 2. & Marketing és reklám & 1 \\
\hline 3. & Munkavállalás és munkakörök & 2 \\
\hline 4. & A turizmus hatása a társadalmi és természeti környezetre & - \\
\hline 5. & Utazásszervezés & 1 \\
\hline 6. & A turizmus fajtái és attrakciói & - \\
\hline 7. & Magyarország, mint turisztikai desztináció & 1 \\
\hline 8. & A célnyelvi országok, mint turisztikai desztinációk & - \\
\hline 9. & Közlekedési formák & - \\
\hline 10. & Szállodaipar, szállodák típusai, szolgáltatások & 1 \\
\hline 11 & Vendéglátóipari üzlettípusok & 1 \\
\hline 12 & Táplálkozási irányzatok & - \\
\hline 13 & A magyar konyha & 1 \\
\hline 14 & A célnyelvi országok gasztronómiája & \\
\hline
\end{tabular}

A projektfeladatok egységes struktúrában készültek el, amelyet az intézmény Oktatásmódszertani Központja dolgozott ki. A projektleírás tartalmazta az adott projekt kereteinek leírását (célcsoport, pedagógia célok, projekt elhelyezkedése a kurzuson belül, alkalmazott munkaformák, csoportszervezés módja, ütemezés, szükséges IKT eszközök), valamint a feladat részletes, lépésenkénti bemutatását (tevékenység, feladat leírása időtartammal, szükséges eszközök, kapcsolódó linkek, csatolmányok, a feladatrészhez kapcsolódó konkrét oktatói tevékenységek leírása, javasolt értékelési mód, elörelátható nehézségek/kockázatok) (1. melléklet). Minden projekthez készült egy részletes tanulói feladatlap, amely tartalmazta a tanórai feldolgozásra javasolt bevezető feladatokat, az önálló projektmunka lépéseit és tevékenységeit a részhatáridőkkel, valamint a projekt eredményeinek bemutatására vonatkozó kritériumokat és az (ön)értékelési szempontokat. 


\section{Kooperáció és önértékelés a szaknyelvi órán - esetleírás}

Kooperáció és önértékelés a szaknyelvi órán címmel módszertani kísérletet végeztem a BGE Turizmus-Vendéglátás szakján. Egyrészt a rendelkezésre álló szaknyelvi tananyag egy jelentős részét a tanári felkészülés során a kooperatív oktatás/tanulás alapelveinek figyelembevételével átdolgoztam, másrészt a tanszéken elkészült projektfeladatok közül három projekt részleges vagy teljes elvégzésére is sor került. A kiválasztott projektek a következö témákhoz kapcsolódtak: a turizmus szerepe a gazdaságban, Magyarország, mint desztináció és a célországok gasztronómiája (2. táblázat).

2. táblázat. Az elvégzett projektfeladatok

\begin{tabular}{|l|l|l|}
\hline \multicolumn{1}{|c|}{ Témakör } & \multicolumn{1}{|c|}{$\begin{array}{c}\text { Konkrét } \\
\text { projektfeladat címe }\end{array}$} & \multicolumn{1}{c|}{ Elvárt output } \\
\hline $\begin{array}{l}\text { A turizmus szerepe a } \\
\text { gazdaságban }\end{array}$ & $\begin{array}{l}\text { Magyarország } \\
\text { turizmusa számokban }\end{array}$ & $\begin{array}{l}\text { Grafikon-elemzést tartalmazó ppt, csoportos } \\
\text { prezentáció, üzleti beszámoló megadott } \\
\text { sablon szerint }\end{array}$ \\
\hline $\begin{array}{l}\text { Magyarország, mint } \\
\text { turisztikai desztináció }\end{array}$ & $\begin{array}{l}\text { Magyarország } \\
\text { turisztikai vonzereje }\end{array}$ & $\begin{array}{l}\text { Interjúk külföldiekkel, ppt, csoportos } \\
\text { prezentáció }\end{array}$ \\
\hline $\begin{array}{l}\text { A célországok } \\
\text { gasztronómiája }\end{array}$ & A brit konyha & Receptkönyv szószedettel és képekkel \\
\hline
\end{tabular}

A kísérletben részt vevő csoport nyelvi szintje meglehetősen jó volt (a többség nyelvtudása megfelelt a $\mathrm{B} 2+$ szintnek a $\mathrm{KER}^{4}$ szerint). A jó szinten könnyedén kommunikáló nyelvtanulók tanulási motivációja általában csökken, mert saját nyelvi fejlődésüket már nehezebben érzékelik. Mivel a tudásuk gyarapodása már nem látványos, a fejlődés megtapasztalása által generált belső motiváció nehezen fenntartható, annak ellenére, hogy a hallgatók általában tisztában vannak azzal, hogy saját felelősségük a nyelvtanulásuk eredményessége szempontjából megelőzi a tanár felelősségét (Szénich - Szokács, 2016). A projektfeladatok bevezetésének éppen ezért a nyelvi fejlődésen túlmutató pedagógia céljai is voltak, mégpedig:

- a tanulási folyamat élményszerüvé tétele az eredményesebb nyelvtanulás érdekében,

- a team-munkában való jártasság növelése,

- a reflektív magatartás kialakítása,

- a saját tanulásért és a csoport eredményeiért vállalt felelősségérzet erősítése.

A hallgatók a kontaktfoglalkozásokon, valamint a projektfeladatokon is négyfós állandó csoportokban dolgoztak, amelyeknek a belső szerveződésébe a tanár nem avatkozott be. A közös munka megszervezése szükségessé tette az egymás közti folyamatos kommunikációt írásban és szóban.

\footnotetext{
${ }^{4}$ Közös Európai Referenciakeret, 2001, Európa Tanács: Strasbourg
} 
A kooperatív oktatás irányába mutató órai feladat-átdolgozások jól működtek. A csoportok hamar teammé váltak. A kommunikáció megélénkült, a szociális kapcsolatok erősödtek. Az önálló projektfeladatok sem váltottak ki ellenállást. A rövidebb, egyszerübb feladatok jól müködtek, motiválók voltak, a csoportok jól együttműködtek. A többlépcsős, nagyobb önállóságot igénylő, vagy a csoporton belül egy vezető irányító munkáját feltételező feladatok vagy feladatrészek nehezebben müködtek. Többszörös magyarázatra volt szükség, az előrehaladás rendszeres ellenőrzésére, a határidők időnkénti módosítására, ami az autonómia és a felelősségvállalás erősítésének szükségességét jelzi.

A munka során a kooperatív tanulás elemei teljesen vagy részben megvalósultak: a Johnson és munkatársai (2014) által meghatározott öt legfontosabb ismérv, az egymásrautaltság, a támogató interakció, az elszámoltathatóság (felelősség), a kooperatív szerepek alkalmazása és a csoport önértékelése végig jellemezte a munkafolyamatot.

Mind a tanórai csoportos feladatoknál, mind pedig a projektmunkában nagy hangsúly került az önértékelés különböző formáira. Az év folyamán több ízben került sor pontozásos formában hallgatói értékelésre, amikor a hallgatók értékelték saját munkájukat, a csoport teljesítményét, a feladatot, valamint a kurzust. Az egyéni hallgatói értékeléseket csoportos értékelés és tanári visszajelzések egészítették ki (3. táblázat).

3. táblázat. Értékelési formák

\begin{tabular}{|c|c|c|c|}
\hline $\begin{array}{c}\text { Hallgatók egyéni } \\
\text { értékelése }\end{array}$ & $\begin{array}{c}\text { Hallgatói } \\
\text { önértékelés }\end{array}$ & $\begin{array}{c}\text { Hallgatói értékelés } \\
\text { kiscsoportban }\end{array}$ & $\begin{array}{l}\text { Tanári } \\
\text { értékelés }\end{array}$ \\
\hline $\begin{array}{l}\text { Csoport munkájának } \\
\text { értékelése (pl. } \\
\text { időtartás, } \\
\text { munkamegosztás, } \\
\text { kommunikáció) } \\
\text { (anonim) }\end{array}$ & $\begin{array}{l}\text { Saját teljesítmény } \\
\text { értékelése értékelő } \\
\text { lappal (anonim) }\end{array}$ & $\begin{array}{l}\text { Csoportvezetők } \\
\text { önértékelése és } \\
\text { csoportértékelése teljes } \\
\text { csoport felé }\end{array}$ & $\begin{array}{l}\text { Tanári értékelés } \\
\text { egyénnek }\end{array}$ \\
\hline $\begin{array}{l}\text { Feladat értékelése } \\
\text { szempontok alapján } \\
\text { (anonim) }\end{array}$ & $\begin{array}{l}\text { Saját teljesítmény } \\
\text { értékelése } \\
\text { kiscsoportban, } \\
\text { tapasztalatok } \\
\text { megosztásával }\end{array}$ & $\begin{array}{l}\text { Csoportmunka } \\
\text { értékelése csoportban } \\
\text { (pl. időtartás, } \\
\text { munkamegosztás, } \\
\text { kommunikáció) }\end{array}$ & $\begin{array}{l}\text { Tanári visszajelzés } \\
\text { csoportnak }\end{array}$ \\
\hline $\begin{array}{l}\text { Szöveg/input } \\
\text { értékelése tartalom és } \\
\text { nehézség alapján } \\
\text { (anonim) }\end{array}$ & & $\begin{array}{l}\text { Tanár-diák csoportos } \\
\text { interjú a projektekröl } \\
\text { és a team-munkáról }\end{array}$ & $\begin{array}{l}\text { Tanári értékelés } \\
\text { teljes csoportnak }\end{array}$ \\
\hline $\begin{array}{l}\text { Félév végi írásos } \\
\text { értékelés a } \\
\text { projektekröl (anonim) }\end{array}$ & & & $\begin{array}{l}\text { Outputok értékelése } \\
\text { osztályzattal }\end{array}$ \\
\hline
\end{tabular}


$\mathrm{Az}$ értékelési folyamatnak talán a legértékesebb része a rendszeres önértékelés volt, amikor a hallgatók egy 1-6-ig terjedő skálán értékelték nemcsak a teljesítményüket, hanem az egyes részfeladatokba befektetett munkát és a feladatokkal kapcsolatos attitüdöt is (4. táblázat). Hallgatói értékelésre mind az órai csoportfeladatok, mind pedig az egyes projektfeladatok elvégzése után, valamint a félév végén is sor került (összesen mintegy tíz alkalommal). A rendszeres önértékelésnek a célja elsősorban a reflektív magatartás kialakítása és a tanulói tudatosság szintjének emelése volt, ami közvetve a felelősségvállalás erősödését célozta.

4. táblázat. Az önértékelés szempontjai

\begin{tabular}{|l|llllll|}
\hline \multicolumn{1}{|c|}{ Kategória } & \multicolumn{6}{c|}{ Értékelés } \\
\hline Folyamatos beszéd & 1 & 2 & 3 & 4 & 5 & 6 \\
\hline Nyelvhelyesség & 1 & 2 & 3 & 4 & 5 & 6 \\
\hline Kontribúció/erőfeszítés & 1 & 2 & 3 & 4 & 5 & 6 \\
\hline Lelkesedés/hajlandóság & 1 & 2 & 3 & 4 & 5 & 6 \\
\hline
\end{tabular}

A félév során három újonnan kifejlesztett projektfeladatot végeztek el a hallgatók négyfős csoportokban. A projektek bemutatása, a feladatok ismertetése és a bevezető feladatok elvégzése a tanórán történt. Ezt követően a hallgatói csoportok 3-4 hétig önállóan dolgoztak (időnként rész-határidőkkel). Az egyes projektek eredménye egy-egy valós nyelvi produktum volt: üzleti beszámoló, csoportos prezentáció és receptkönyv, amelyeknek a létrehozásán közösen kellett dolgozni. Végül szóbeli prezentációban vagy írásos formában mutatták be a munkájuk közös eredményét. Az egyes projektfeladatok után projektértékelö lapot töltöttek ki a hallgatók, ahol 1-5-ig terjedő Likert-skálán kellett jelezniük egyetértésük mértékét a megadott állításokkal. Az állítások tartalma a feladat jellemzőitől a csoportmunka értékelésén át a nyelvi teljesítményig terjedt. $A$ Magyarország turizmusa számokban címü projekt (5. táblázat) értékelése jól mutatja, hogy bár a feladatot nem találták különösebben érdekesnek a hallgatók, a csoportmunkát az átlagosnál kedvezőbben ítélték meg és a munka hasznosságát is elismerték, amikor fejlődésről számoltak be nyelvi vonatkozásban.

5. táblázat. A Magyarország turizmusa számokban c. projekt értékelése Likert-skálán (1-5) $(\mathrm{n}=16)$

\begin{tabular}{|l|l|}
\hline \multicolumn{1}{|c|}{ KONKRÉT PROJEKTFELADAT } & Átlag \\
\hline 1. A feladat inspiráló volt. & 2,8 \\
\hline 2. A feladat nehéz volt. & 2,0 \\
\hline 3. A feladat túl sok munkát igényelt & 2,8 \\
\hline
\end{tabular}




\begin{tabular}{|l|l|}
\hline 4. A projektmunka inspiráló volt. & 2,7 \\
\hline 5. Kiváló volt az együttmüködés a csoportomban. & 3,4 \\
\hline 6. A munkát egyenlően osztottuk el. & 3,6 \\
\hline 7. Szerettem csoportban dolgozni. & 3,8 \\
\hline 8. Elégedett vagyok a részvételemmel. & 3,2 \\
\hline 9. Sok erőfeszítést tettem bele a munkába. & 2,9 \\
\hline 10. Többet dolgoztam a projektben, mint a többiek. & 2,1 \\
\hline 11. Kevesebbet dolgoztam a projektben, mint a többiek. & 2,3 \\
\hline 12. Sokat tanultam a magyarországi turizmusról. & 2,6 \\
\hline 13. Most jobb vagyok a grafikon-leírásban, mint korábban. & 3,7 \\
\hline 14. A nyelvi készségeim fejlődtek. & 3,2 \\
\hline 15. Az órán kívül is általában angolul beszéltünk, amikor a projekten dolgoztunk. & 4,5 \\
\hline
\end{tabular}

A kurzus végi önértékelés során egyrészt saját munkájukat értékelték egy 1-6-ig terjedő skálán hat különböző szempontból, a részvételtől, a pontosságon, a hajlandóságon és igyekezeten át a csoportmunka-tapasztalatig és a teljesítményig (6. táblázat), másrészt a nyelvi fejlődésük mértékét becsülték meg a hallgatók (7. táblázat).

6. táblázat. Önértékelés. A kísérleti csoport eredményei $(n=16)$

\begin{tabular}{|l|c|}
\hline \multicolumn{1}{|c|}{ Kategóriák } & Önértékelés 1-6- skálán \\
\hline Óralátogatás & 5,0 \\
\hline Erőfeszítés, igyekezet & 3,8 \\
\hline Teljesítmény & 3,9 \\
\hline Hajlandóság a házi feladatok megírására & 4,0 \\
\hline Határidők tartása & 4,3 \\
\hline Nyelvi fejlődés & 4,4 \\
\hline Csoportmunkában való részvétel & 4,4 \\
\hline Hajlandóság a jelenlegi csoporttal történő további munkára & 4,2 \\
\hline
\end{tabular}

A nyelvi fejlődés megbecsülése nem Likert-skálával történt, hanem rubrikák beikszelésével, mert félő volt, hogy a számokat osztályzatnak tekintik a hallgatók és ez torzítja az eredményt. Az egyes kategóriákat értelmeztük, majd sor került a táblázat anonim kitöltésére. A válaszokat ezt követően konvertáltam számokká oly módon, hogy a Sokat fejlődtem válasz kapta az 5-ös értéket. Az eredmények rávilágítanak a kurzus két kiemelt fejlesztési területére: a szókincsbővítésre és az üzleti levelezésre. A kurzus sikerének könyvelhető el az a tény, 
hogy a csoport ezen a két területen érzékelte a legnagyobb fejlődést. Ugyanakkor az is nyilvánvaló, hogy a hallgatók nyelvi önbizalma fejlesztésre szorul.

7. táblázat. Jelezze a táblázatban X-szel, hogy véleménye szerint mennyire fejlődött az alábbi területeken.

A kísérleti csoport eredményei $(\mathrm{n}=16)$

\begin{tabular}{|l|l|l|l|l|l|c|}
\hline Kategória & sokat & $\begin{array}{c}\text { vala- } \\
\text { mennyit }\end{array}$ & $\begin{array}{c}\text { nem } \\
\text { tudom }\end{array}$ & kicsit & semmit & $\begin{array}{c}\text { Nyelvi fejlödés } \\
\text { mértéke: } 1-5 \\
\text { skála }\end{array}$ \\
\hline Nyelvtan & & & & & & 3,4 \\
\hline Szókincs & & & & & & 4,5 \\
\hline Hallásértés & & & & & & 3,5 \\
\hline Beszédkészség & & & & & & 3,6 \\
\hline Szövegértés & & & & & & 3,9 \\
\hline Levélírás & & & & & & 4,1 \\
\hline Folyékonyság & & & & & & 3,5 \\
\hline Önbizalom & & & & & & 3,1 \\
\hline
\end{tabular}

\section{Konklúzió}

A Kooperáció és önértékelés a szaknyelvi órán címü oktatási kísérletet sikeresnek ítélhetjük. A csoportmunka uralkodóvá vált a kontaktórákon és az önálló, tanórán kívüli csoportos projektmunka bevezetése is eredményesnek bizonyult. Ezen a kurzuson három projektfeladat elvégzésére került sor, és elmondhatjuk, hogy a projektek kidolgozásakor kitüzött célok mindegyike megvalósult a munka során (8. táblázat). A feladat elvégzése során a hallgatók valós feladatokat teljesítettek (valós élményeket szereztek) önállóan vagy csoportban, integrálniuk kellett szakmai és nyelvi ismereteiket és készségeiket (pl. interjú külföldiekkel, statisztikai adatok gyüjtése), új kommunikációs műfajokban szereztek jártasságot (pl. prezentáció, üzleti beszámoló), tapasztalatot szereztek a team-munkában és megtapasztalták azt a valós helyzetet, amikor a csoport minden tagja felelős az eredményért. A részfeladatokat ugyanis lehetett egyénileg is elvégezni, de a végső produktum tartalmi és formai megszerkesztése és a prezentálás módja közös döntéseket igényelt. Mivel a produktum került értékelésre (osztályzásra), az egyes csoporttagok munkája befolyásolta a társak eredményét is. Az egymás iránti felelösséget - különösen a félév elején - kiemelten hangsúlyozni kellett, a folyamatos közös munka azonban meghozta a gyümölcsét, amelynek egyik látványos eredménye volt a hiányzások számának csökkenése. 
8. táblázat. A célok megvalósulása a kurzus során

\begin{tabular}{|l|l|}
\hline \multicolumn{1}{|c|}{ Cél } & \multicolumn{1}{c|}{ Megvalósulás (példák) } \\
\hline $\begin{array}{l}\text { Szakspecifikus szakmai } \\
\text { ismeretek és készségek } \\
\text { bövítése }\end{array}$ & $\begin{array}{l}\text { Magyarország turisztikai vonzereje valós adatgyüjtés alapján } \\
\text { (interjúk); statisztikai adatok gyüjtése és elemzése; grafikon } \\
\text { készítése; ételnevek, ételkészítési módok megismerése }\end{array}$ \\
\hline $\begin{array}{l}\text { Idegennyelv-tanulási és } \\
\text { kommunikációs célok }\end{array}$ & $\begin{array}{l}\text { Új kommunikációs müfajok elsajátítása (csoportos } \\
\text { prezentáció, üzleti beszámoló, grafikon-leírások, ételrecept } \\
\text { stb.). Csoportmunka által generált kommunikációs helyzetek } \\
\text { (beszélöváltás, vita, meggyözés stb.) }\end{array}$ \\
\hline $\begin{array}{l}\text { Társas készségek } \\
\text { fejlesztése }\end{array}$ & $\begin{array}{l}\text { A döntések és a munka megszervezése folyamatos } \\
\text { együttmüködést igényelt (kompromisszum-kötés, különböző } \\
\text { vélemény/különböző munkastílus elfogadása, egymás } \\
\text { segítése, empátia stb.) }\end{array}$ \\
\hline $\begin{array}{l}\text { Módszertani cél: } \\
\text { élményalapú tanulás a } \\
\text { hatékonyság növelésére }\end{array}$ & $\begin{array}{l}\text { Interjúk készítése külföldiekkel, receptkönyv összeállítása } \\
\text { képi anyaggal, tudásmegosztási lehetőség a csoportokon belül, } \\
\text { önmagukban is értékes/érdekes produktumok létrehozása (pl. } \\
\text { receptkönyv) }\end{array}$ \\
\hline $\begin{array}{l}\text { Nyelvtanuláson túlmutató } \\
\text { tanulási célok: önállóság és } \\
\text { felelősségtudat }\end{array}$ & $\begin{array}{l}\text { Folyamatos önértékelés a saját felelösség felismerésére. A } \\
\text { projekt outputok* csoportonként készültek el és kerültek } \\
\text { értékelésre (osztályzásra), ami növelte a csoporttagok egymás } \\
\text { iránti felelösségét. }\end{array}$ \\
\hline
\end{tabular}

* Lásd 2. táblázat

Hangsúlyos említést érdemel a félév során következetesen alkalmazott értékelési rendszer, ami a csoportos interjú tanúsága szerint jelentősen hozzájárult a tanulói tudatosság erősítéséhez, keretbe foglalta a félévi munkát és ezzel fegyelmezettebbé és célzottabbá tette a tanítási/tanulási folyamatot. Ugyanakkor szükség lehet az értékelésnek a továbbfejlesztésére, elsősorban a tanár részéröl, hogy az egyéni és a csoportos teljesítmény megfelelö módon jelenhessen meg a kurzust lezáró érdemjegyben.

A jövőre nézve a tanári tapasztalatok közül elsősorban a projektek nagyon alapos és részletes előkészítésének fontosságát emelhetjük ki, továbbá érdemes a csoport szerveződésére és a csoporton belüli szerepekre is nagyobb figyelmet fordítani. 


\section{Hivatkozások}

Andresen, L. - Boud, D. - Cohen, R. (2011): Experience-based learning. In: Foley, G. (ed.) (2011): Understanding Adult Education and Training. (225-239) (2nd Edition). Allen \& Unwin: Sidney. Elérhető online: http://complexworld.pbworks.com/f/Experiencebased\%2520learning.pdf. DOI: https://doi.org/10.4324/9781003118299-22

Bakti, M. - Csetényi, K. - Juhász, V. - Szarvas, J. (2018): Legyen élmény a nyelvtanulás! Élményalapú, informális idegennyelv-tanitási módszertan. [output] Szegedi Tudományegyetem: EFOP-3.2.14-17-2017-00001 pályázat: Elérhető online: https://arts.u-szeged.hu/download.php?docID=87064

Bodnár, Zs. (2014): Tudásmegosztás - kivel, mikor, hogyan? Elérhető online: https://recity.hu/tudasmegosztas-kivel-mikor-hogyan/

Condliffe, B. - Quint, J. - Visher, M. G. - Bangsher, M. R. - Drohojowska, S. - Saco, L. Nelson, E. (2017): Project-based learning. A literature review. MDRC. Elérhető online: https://www.mdrc.org/sites/default/files/Project-Based_Learning-LitRev_Final.pdf

Council of Europe (2016): Competences for democratic cultures. Council of Europe: Strasbourg

Edwards, R. (1997): Changing places? Flexibility, lifelong learning, and a learning society. Routledge: New York.

Gönczöl, E. (2009): A tudásmegosztás formális és informális közösségei. Elérhető online: https://osztalyfonok.hu/cikk.php?id=677

Gibbes, M. - Carson, L. (2013). Project-based language learning: An activity theory analysis. Innovation in Language Learning and Teaching. 8/2. 171-189. Elérhető online: https://www.researchgate.net/publication/257227146_Projectbased_language_learning_An_activity theory_analysis. DOI: https://doi.org/10.1080/17501229.2013.793689

Henry, K. (2005): Teaching through projects. Routledge: London-New York

Jakabné Balla, I. - Balla, Á. (2012). Változó szakmai igények a munkaeröpiacon. [Disszeminációs füzetek 35]. Tempus: Budapest. Elérhető online: https://tka.hu/docs/palyazatok/valtozo_szakmai_igenyek_a_munkaeropiacon.pdf

Johnson, D. W. - Johnson, R. - Smith, K. A. (2014): Cooperative learning: Improving university instruction by basing practice on validated theory. Journal on Excellence in College Teaching, 25/3-4. 85-118. Elérhető online:

https://www.researchgate.net/publication/284471328_Cooperative_Learning_Improving _university_instruction_by_basing_practice_on_validated_theory

Kauchak, G. - Eggen, P. (2012): Learning an teaching. Research-based methods. Pearson: Boston

Kolb, A. Y. - Kolb, D. A. (2013): The Kolb Learning Style Inventory - Version 4.0. A Comprehensive Guide to the Theory, Psychometrics, Research on Validity and Educational Applications. Experience Based Learning Systems, Inc.: Kaunakakai, HI. Elérhető online: https://learningfromexperience.com/downloads/research-library/thekolb-learning-style-inventory-4-0.pdf

Koltói, L. (2009): Tudásmegosztás és-teremtés tanárok online szakmai közösségében Iskolakultúra Online 2. 42-51. Elérhető online: http://misc.bibl.uszeged.hu/45539/1/iol_2009_002_042-051.pdf

Lee, J. S. - Blackwell, S. - Drake, J. - Moran, K. A. (2014): Taking a Leap of Faith: Redefining Teaching and Learning in Higher Education Through Project-Based Learning. Interdisciplinary Journal of Problem-Based Learning, 8/2. DOI: https://doi.org/10.7771/1541-5015.1426

London, M. (Ed.) (2011): The Oxford handbook of life-long learning. OUP: Oxford. Elérhető online:

https://www.oxfordhandbooks.com/view/10.1093/oxfordhb/9780195390483.001.0001/o 
xfordhb-9780195390483-e-001. DOI:

https://doi.org/10.1093/oxfordhb/9780195390483.001.0001

Sándor, E. - Szirtesné, Kis, Á. (2016): Kooperatív tanulás a szaknyelvoktatásban. Egy módszertani kísérlet tapasztalatai. In: Loch, Á. - Dévény, Á. (szerk.) (2016):

Módszertani kisérletek a nyelvoktatásban. Motiváció és eredményesség. BGE: Budapest

Szénich, A. - Szokács, K. (2016): Tudok-e egyedül tanulni? A hallgatók önálló nyelvtanulási képességének és hajlandóságának vizsgálata az üzleti felsőoktatás kontextusában. In: Loch, Á. - Dévény, Á. (szerk.) (2016): Módszertani kísérletek a nyelvoktatásban. Motiváció és eredményesség. BGE: Budapest

Thomas, J. W. (2000): A review of research on project-based learning. Autodesk Foundation: San Rafael, CA Elérhető online: https://pdfs.semanticscholar.org/8d83/f329aac63db3c67599f76323e37ace4a53bd.pdf

Török, J. - Kétyi, A. (2018): Projektúra: a projektalapú nyelvtanulás német szaknyelvi csoportokkal. Multidiszciplináris kihívások, sokszínü válaszok. 2018/3. 96-110. Elérhető online: https://ojs3.mtak.hu/index.php/mksv/article/view/1877 
1. melléklet. A Magyarország turizmusa számokban c. téma lépései

\begin{tabular}{|c|c|c|c|c|}
\hline & Tevékenység & Output & $\begin{array}{l}\text { Eszközök, linkek, } \\
\text { csatolmányok }\end{array}$ & Oktatói feladatok \\
\hline 1 & $\begin{array}{l}\text { Magyarország turizmusával } \\
\text { kapcsolatos szöveg feldolgozása. A } \\
\text { beszámoló, mint írásbeli müfaj } \\
\text { jellemzőinek bemutatása ( } 90 \text { perces } \\
\text { tanóra). }\end{array}$ & $\begin{array}{l}\text { Szószedet, } \\
\text { Kitöltött szókincs-feladatok. }\end{array}$ & $\begin{array}{l}\text { Írott tananyagok. Aktuális } \\
\text { cikkek a témáról. Írásos } \\
\text { beszámolóhoz minták. }\end{array}$ & $\begin{array}{l}\text { A téma felvezetése. Kapcsolódó szókincs- } \\
\text { feladatok összeállítása. Szövegértés ellenőrzése. } \\
\text { Ismeretanyag elsajátíttatása. A beszámoló, mint } \\
\text { írásbeli üzleti mủfaj bemutatása, minta } \\
\text { beszámolók gyüjtése. }\end{array}$ \\
\hline 2 & $\begin{array}{l}\text { Grafikon-leírás ( } 90 \text { perc tanóra }+45 \\
\text { perc egyéni otthoni feladat). }\end{array}$ & $\begin{array}{l}\text { Megoldott feladatok } \\
\text { (feladatlap). }\end{array}$ & $\begin{array}{l}\text { Internetes források. Coospace-en } \\
\text { biztosított anyagok és müfaji } \\
\text { modellek. Feladatlap. } \\
\text { www.ksh.hu }\end{array}$ & $\begin{array}{l}\text { Speciális lexikai gyüjtemény összeállítása. } \\
\text { Feladatlapok és megoldó kulcsok összeállítása. } \\
\text { Órai gyakoroltatás. Javítási feladatok. }\end{array}$ \\
\hline 3 & $\begin{array}{l}\text { Adatok és információ gyüjtése a } \\
\text { választott témában. Szószedet } \\
\text { készítése a témához (A projekt } \\
\text { bevezetéséhez: } 45 \text { perc tanórán }+ \\
\text { min. } 2 \text { óra órán kívüli munka). }\end{array}$ & $\begin{array}{l}\text { Összegyüjtött anyagok } \\
\text { (grafikonok, adattáblázatok, } \\
\text { hírek, cikkek stb.) } \\
\text { tematikusan elrendezve, } \\
\text { szószedet. }\end{array}$ & $\begin{array}{l}\text { Google.doc javasolt, hogy a } \\
\text { csoporttagok egymás munkáját } \\
\text { nyomon követhessék. Internetes } \\
\text { források. KSH adatbázisa. } \\
\text { Hasznos linkek. }\end{array}$ & $\begin{array}{l}\text { A projekt bevezetése, a feladat részletes kiadása. } \\
\text { A csoportok összeállítása és a témaválasztás } \\
\text { irányítása. Források megadása. Folyamatos } \\
\text { konzultációs lehetóség személyesen és } \\
\text { elektronikusan. }\end{array}$ \\
\hline 4 & $\begin{array}{l}\text { Az összegyüjtött anyagok alapján } \\
\text { rövid beszámoló készítése a } \\
\text { magyarországi turizmus választott } \\
\text { szegmenséröl ( } 3 \text { óra). }\end{array}$ & Beszámoló (business report) & $\begin{array}{l}\text { Google.doc javasolt a közös } \\
\text { munkához. Csoport által } \\
\text { összegyüjtött adatok és } \\
\text { információk. Beszámolóhoz } \\
\text { sablon. }\end{array}$ & $\begin{array}{l}\text { Előzetesen: a hatékony prezentáció tényezőinek } \\
\text { bemutatása (tanári prezentáció + videófilm). } \\
\text { Sablon készítése a beszámolóhoz. Folyamatos } \\
\text { konzultációs lehetőség biztosítása személyesen } \\
\text { és elektronikusan. }\end{array}$ \\
\hline 5 & $\begin{array}{l}\text { Prezentációk készítése és } \\
\text { bemutatása a teljes } \\
\text { tanulócsoportnak ( } 8-10 \text { perc). } \\
\text { Minden prezentációhoz feladatlapot } \\
\text { is készítenek a csoportok. A } \\
\text { hallgatóság kitölti a feladatlapot és } \\
\text { értékelőlap alapján értékel. }\end{array}$ & $\begin{array}{l}\text { ppt vagy prezi prezentáció, } \\
\text { feladatlap. }\end{array}$ & PC és projektor (prezi vagy ppt). & $\begin{array}{l}\text { Prezentációs értékelőlap elkészítése. A } \\
\text { prezentációk értékelése tartalmi, nyelvi, formai } \\
\text { és előadói szempontból. A hallgatóságtól } \\
\text { begyüjtött értékelölapok elemzése, összegzése. } \\
\text { Feladatlapok ellenőrzése. }\end{array}$ \\
\hline 6 & $\begin{array}{l}\text { Egyéni feladat- csoport- és } \\
\text { önértékelés ( } 20 \text { perc). }\end{array}$ & Kitöltött értékelő lapok. & Értékelési ürlapok. & $\begin{array}{l}\text { Értékelési szempontrendszer összeállítása. Az } \\
\text { önértékelés típusainak bemutatása. A munka } \\
\text { monitorozása. }\end{array}$ \\
\hline
\end{tabular}

